\title{
The European Citizens' initiative: too much democracy for EU polity?
}

\author{
Erik Longo*
}

(Received 17 December 2018; accepted 20 January 2019)

\begin{abstract}
This Article analyzes the state of democracy in the EU through the study of the European Citizens' Initiative. The European Citizens' Initiative (ECI) represents one of the main ways the European institutions chose during the making of the European Convention, and then reproduced in the Lisbon Treaty, to beat populism by bringing decision-making closer to the citizens and promoting a new legitimization of Europe's political unity. This Article starts by arguing that if one wants to understand European versions of populism it is necessary to pay attention to the reason why "democratic deficit" and "Euroscepticism" are predominant problems that the European Union is facing. It then analyzes the implementation of the ECI and the main issues of this instrument of democratization pointing at three flaws: a) the problem of $e$-democracy; b) the difficulty of stimulating large participation of civil society and people for the purposes of the ECIs; c) the cumbersome role of the EU Commission and the difficulties to ensure a real participatory instrument for the European citizens. From the analysis of the ECI this Article first advocates for a more robust public sphere in Europe as indispensable ground for a supranational democracy; second, it supports the revision of the ECI procedural aspects to transform it into a viable channel for amending EU policies in a more democratic way; third, this Article participates in the debate over the brand of democracy most suited to EU governance and polity.
\end{abstract}

Keywords: European Union; European Citizens' Initiative; Democratic deficit and Euroskepticism; electronic democracy

\section{A. Introduction}

The European Union's "democratic deficit" is undeniable, without any mention of the arguments one can found in the vast literature on this topic. ${ }^{1}$ In the context of the EU, with which this Article

${ }^{\star}$ Erik Longo is an associate professor of Constitutional Law, Department of Law, University of Florence (Italy). E-mail: erik.longo@unifi.it. The author would like to thank Oran Doyle and Andrea Pin for their valuable comments. The usual disclaimer applies.

1"The claim that the EU was in democratic deficit reflected not a democratic past that was eroding, but rather the growing democratic expectations that came with political integration, combined with institutions - the European Parliament in particular - that can and should be measured according to democratic norms." Mark E. Warren, Citizen Participation and Democratic Deficits: Considerations from the Perspective of Democratic Theory, in ACTIVATING THE CiTIZEN, 17, 18 (Joan DeBardeleben \& Jon H Pammett eds., 2009). The term "democratic deficit" originated in discussions about the political integration of the European Union. For more, see Gráinne De Búrca, The Quest for Legitimacy in the European Union, 59 Mod. L. Rev., 349 (1996); Joseph H. H. Weiler, et al., European Democracy and its Critique, 18 W. Eur. PoL. 4-39 (1995); Neil MacCormick, Questioning Sovereignty Law, State, and Nation in the European Commonwealth 137-158 (1999); Joseph H. H. Weiler, Why Should Europe be a Democracy: The Corruption of Political Culture and the Principle of Constitutional Tolerance, in The Europeanisation of LAw: The Legal EfFects of European InTEgRATION, 213-19 (Francis Snyder ed. 2000); Richard Bellamy \& Dario Castiglione, The Uses of Democracy: Reflections on the European Democratic Deficit, in Integration through Deliberation? On the Prospects for European Democracy, 65-84 
is predominantly concerned, the deficit of popular support has frequently been taken as one of the main obstacles on the road towards "an ever-closer union among the people of Europe," as the original motto predicted, sketching the transformation of the Communities into something more than just a model of economic and political governance or a successful example of globalization. ${ }^{3}$

Today, the tolerance of a not-completely democratic Europe is at its lowest level since the beginning of the twenty-first century. ${ }^{4}$ The crisis of the Eurozone and, in turn, the unwilling acceptance of austerity measures, the populist backlash, and the reshuffling of global power in the Trump era have alarmed politicians and academics alike across Europe. ${ }^{5}$ The fear of an imminent end of a Europe consisting of people living in peace and prosperity lingers in the corridors of power in many European nations. ${ }^{6}$ The intensity of clashes between pro and anti-European leaders is fostering some critical self-reflection in the EU and providing an impetus to fix some of the "constitutional mistakes" made during the last thirty years. ${ }^{7}$

Indeed, by taking democratic legitimacy for granted and inviting us to surrender to what will end up being imposed (e.g., the homework given to the most indebted states), EU integration, as a process established from the top down, has had a corrosive effect on European polity, ${ }^{8}$ delegitimizing the very idea of Europe's political unity, ${ }^{9}$ and at the same time contributing to the growing spread of anti-EU populist movements. ${ }^{10}$ Because of the evident deficiencies of the European project, the only powerful narratives that seem to be standing are populist rebuttals fed by the evil game of "blaming Brussels" and-above all-by the conclusion that EU institutions are democratically delegitimized and not more able to ensure basic public goods-such as employment, security, currency, etc. ${ }^{11}$

Now that an impasse has been reached and the next elections for the European Parliament are closer, the conclusion is stark: If the EU wants to survive and re-present itself as a credible and attractive shared project, a complete turnaround in the legitimacy underlying European governance is necessary. Namely, one that allows a reform of processes and structures that would replicate, at the European level—even with the imperfect practice of governmental control—the principles of

(Erik O. Eriksen \& John E. Fossum eds., 2000); Andreas Follesdal \& Simon Hix, Why There is a Democratic Deficit in the EU: A Response to Majone and Moravcsik, 44 JCMS: J. Common MKT. STUD., 533-562 (2006); Mark Bovens, et al., The EU's Accountability Deficit: Reality or Myth?, in The Real World of EU Accountability. What Deficit?, 1-8 (Mark Bovens, et al. eds., 2010); Yves Mény, Can Europe Be Democratic? Is It Feasible? Is It Necessary? Is the Present Situation Sustainable?, 34 Fordham Int'L L.J. 1287 (2010); Vivien A Schmidt, Democracy in Europe: The EU AND NATional polities (2006); Dimitris N Chryssochoou, Theorizing European INTEgration (Routledge II ed. 2009).

${ }^{2}$ Consolidated Version of the Treaty on European Union, art. 1(2), Mar. 30, 2010, 2010 O.J. (C 83 ) 15 [hereinafter TEU].

${ }^{3}$ Beatriz Pérez de las Heras, Introduction, in Democratic Legitimacy in the European Union and Global Governance: Building a European Demos, 1 (Beatriz Pérez de las Heras ed. 2016).

${ }^{4}$ See Mark Dawson, The Legal and Political Accountability Structure of 'Post-Crisis' EU Economic Governance, 53 JCMS: J. of Common Mкт. STUd., 978-83 (2015); Michael A. Wilkinson, Authoritarian Liberalism in the European Constitutional Imagination: Second Time as Farce?, 21 ELJ 313-39 (2015).

${ }^{5}$ As it is extensively documented by the special issue on "Liberalism" in the magazine The Economist. See Reinventing Liberalism for the 21st Century, 175 ECONOMIST 1-2 (Sep. 13, 2018).

${ }^{6}$ As the lively words of Joseph Weiler expressed, in Europe we have seen a shift of mentality, from "integration through law" to "integration through fear." Joseph H. H. Weiler, Editorial: Integration Through Fear, 23 EUR. J. INT'L L., 1-5 (2012).

${ }^{7}$ See Michael A Wilkinson, The Specter of Authoritarian Liberalism: Reflections on the Constitutional Crisis of the European Union, 14 German L.J 530 (2013); Simon Usherwood, Britain and Europe: A Model of Permanent Crisis?, in THE EUROPEAN Union IN CRIsIs 3-14 (Kyriakos N. Demetriou ed. 2015).

${ }^{8}$ Ulrich Beck, German Europe 10-13 (2013).

${ }^{9}$ Fritz W Scharpf, Governing in Europe: EFFective AND Democratic? 69 (1999).

${ }^{10}$ Daniel Innerarity, Democracy in Europe: A Political Philosophy of the EU 4-13 (2018); Philomena Murray \& Michael Longo, The Crisis-Legitimacy Nexus in the European Union, in The European UnION IN Crisis, ExplORATIONS IN Representation and Democratic Legitimacy 59-74 (Kyriakos N. Demetriou ed. 2015); Todd Huizinga, The New Totalitarian Temptation: Global Governance and the Crisis of Democracy in Europe 43 (2016).

${ }^{11}$ Jan-Werner Müller, Beyond Militant Democracy?, 73 New Left Rev. 39, 44 (2012); Mattias Kumm \& Victor Ferreres Comella, The Primacy Clause of the Constitutional Treaty and the Future of Constitutional Conflict in the European Union, 3 INT'L J. CONST. L. 487 (2005). 
parliamentary accountability, administrative accountability, and citizens' participation, which are the norm in various Member States. ${ }^{12}$ Only the creation of a more democratic environment and the combined effect of a new public sphere that bridges the gap between the national and the European political realms would help the European Union to be more democratic, intelligible, pluralistic, and tolerant. ${ }^{13}$ The challenge lies in "creating a democratic space within which the Member States' citizens of diverse cultural, political and historical backgrounds and identities may see themselves as part of the same supranational democracy." 14

One answer to the quest for a more democratically legitimate Union and fulfilling citizens' expectations towards political institutions-which are channeled today mainly into the radical message of populists - is surely the increase of participation and the broad access to the deliberative processes. ${ }^{15}$ It is under these auspices that the Treaty reform in Lisbon introduced the "European Citizens' Initiative" (ECI), as an innovative tool to bring the people into the debates of policy and law-making at the EU level by supporting and submitting legislative initiatives to the Commission. ${ }^{16}$ The ECI aimed at setting the scene for a new dialogue among political institutions, civil societies, and people in order to "translate the social realm shaped by citizens making use of their rights and freedoms... into a political will." ${ }^{17}$

This Article, thus, will investigate the major problems of the EU democratic fabric through the study of the implementation of the ECI, considering it one of the main ways the European institutions chose during the making of the European Convention, and then reproduced in the Lisbon Treaty, to beat populism by bringing decision-making closer to the citizens and promoting a new legitimization of Europe's political unity. ${ }^{18}$ From the analysis of the ECI, this Article first argues for reinvigorating the European public sphere; second, it supports the revision of the ECI procedural aspects in order to transform it into a viable channel for amending EU policies in a more democratic way; third, it participates in the debate over the particular brand of democracy most suited to EU governance and, therefore, is capable of tackling the regressions and even the possibility of European disintegration. ${ }^{19}$

\footnotetext{
${ }^{12} \mathrm{~A}$ transformation that obviously goes beyond the achievements of the Lisbon Treaty and would be difficult to be accepted by Germany, as Müller suspects. See Müller, supra note 11, at 45. For a summary of the important changes of the last two decades, see Delia Ferri, Participation in EU Governance: A "Multi-Level" Perspective and a "Multifold" Approach, in Citizen PARTICIPATION IN MUlTi-Level DEMOCRACIES 335-37 (Cristina Fraenkel-Haeberle, et al. eds., 2015). For the opinion that sees the impossibility to replicate at the EU level the democratic shape of sovereign states, see Robert A. Dahl, Is International Democracy Possible? A Critical View, in Democracy AND FEDERALISM IN THE EUROPEAN UNION AND THE United States. Exploring Post-National Governance 194-204 (Sergio Fabbrini ed. 2005); Robert Grzeszczak, Comment on Niels Petersen-A Democratic Union: Coherent Constitutional Principle or Prosaic Declaration of Intent?, 6 GERMAN L.J. 1528-29 (2005).

${ }^{13}$ As Philippe C. Schmitter, Revising Some 'Modest Proposals' for Making the European Union More Democratic, in Institutional Challenges in Post-Constitutional Europe, 95-107, 104 (Catherine Moury \& Luis de Sousa eds., 2009) remembers, there is considerable evidence that within the EU individuals and groups have become aware of how many of the decisions have been taken "in a remote, secretive, unintelligible and unaccountable fashion" and that they are "rightly or wrongly, at the mercy of a process of integration that they do not understand and certainly do not control." On the issue of the democratic space and the common identity, see also Dimitris N. Chryssochoou, Europe's Contested Democracy, in European Union Politics, 382-86 (Michelle Cini \& Nieves Pérez-Solórzano Borragán eds., 2010).

${ }^{14}$ See Mayte Peters, The Democratic Function of the Public Sphere in Europe, 14 German L.J. 678 (2013).

${ }^{15}$ Jürgen Habermas, Three normative models of democracy, 1 CONSTELLATIONs 1 (1994).

${ }^{16}$ Luis Bouza Garcia \& Susana Del Río Villar, The ECI as a Democratic Innovation: Analysing its Ability to Promote Inclusion, Empowerment and Responsiveness in European Civil Society, 13 PersP. ON EUR. POL. AND SOC'Y 312-24 (2012).

${ }^{17}$ Peters, supra note 14 , at 680 .

${ }^{18}$ See Rudolf Hrbek, National and European Political Parties and the European Citizens' Initiative, 13 PERSP. ON EUR. POLITICS AND SOC'y 370-84 (2012); For a summary of the discussions on democracy during the two moments, see Niels Petersen, The Democracy Concept of the European Union: Coherent Constitutional Principle or Prosaic Declaration of Intent?, 6 GERMAN L.J. 1511-1513 (2005).

${ }^{19}$ Hans Vollaard, European Disintegration. A Search for Explanations (2018).
} 


\section{B. European populism, democratic deficit, and Euroscepticism: three elements of an incomplete process}

At a time when the various integration legitimacies have been weakened, a time when the European project cannot turn to vigorous achievements or the favor of effectiveness, the only powerful accounts that seem to prevail are Euroscepticism and populist accusation and, above all, the curse that EU institutions are not up to the problems they need to manage. ${ }^{20}$ From the end of the twentieth century, the EU has been considered to have suffered from a substantial legitimacy crisis, which combines the symptoms of a structural democratic deficit on the one hand and a general lack of solving common problems effectively on the other. ${ }^{21}$ Therefore, if we want to analyze populism at the EU level, we must pay attention to the reason for the democratic deficit and Euroscepticism as predominant narratives for describing the democratic challenge European Union is facing. ${ }^{22}$ At first sight, the study of these topics leaves scholars with a sense of fuzziness and elusiveness. Today, populism - as an indeterminate anti-establishment logic ${ }^{23}$ - seems to touch on everything and to be found in every development of the political field at the European level. ${ }^{24}$ The sense and definitions of the two other expressions above mentioned are narrower but multi-faceted. We speak of "democratic deficit" as a synthesis of the legitimacy flaws affecting the European Communities and now the Union, for example the deficiency of some of the basic features of every parliamentary or representative democracy. ${ }^{25}$ At the same time, Euroscepticism refers to opposition, either from right or left, ${ }^{26}$ to some aspects of European integration and the effects of this over time-such as EU enlargement, the austerity measures, or the immigration policy. ${ }^{27}$

The major issue pertaining to these concepts is the evidence that they do not say anything about why opposition or antagonism exists, what form they should take, to what they should apply, nor to what end. They only register reactions fueled by the belief that democratic systems have not completely responded to the needs and desires of the "real people" or the "silent majority"; ${ }^{28}$

\footnotetext{
${ }^{20}$ As Cesare Pinelli remembers, the EU is the "main victim" of populist dynamics. Cesare Pinelli, The Populist Challenge to Constitutional Democracy, 7 Eur. ConsT. L. Rev. 5 (2011)

${ }^{21}$ Jan-Hendrik Kamlage \& Patrizia Nanz, Crisis and Participation in the European Union: Energy Policy as a Test Bed for a New Politics of Citizen Participation, 31 GLOB. Soc'y 65-82 (2017).

${ }^{22}$ Wilkinson, supra note 7 , at 531.

${ }^{23}$ Peter Wiles, A Syndrome, Not a Doctrine: Some Elementary Theses on Populism, in PopUlism: ITS MEANING AND National Characteristics (Ghita Ionescu \& Ernest Gellner eds., 1969); ERnesto LaClau, Politics and IDEOlOGY IN MarXist theory: Capitalism, fascism, POPUlism (1977); Ludovico Incisa, Populismo, in Dizionario Di POlítica 859 (Noberto Bobbio, et al. eds., 1990); Gianfranco Pasquino, Populism and Democracy, in TwENTY-FIRST CENTURY populism: The spectre of Western European Democracy (Daniele Albertazzi \& Duncan McDonnell eds., 2007); Cas Mudde \& Cristóbal Rovira Kaltwasser, Populism: a Very Short Introduction (2017); Paul Blokker, Populist Constitutionalism, in Routledge Handbook of Global Populism (Carlos de la Torre ed. 2018); Ángel Rivero, Populism and Democracy in Europe, in Routledge Handbook of Global Populism 295-308 (Carlos de la Torre ed. 2018).

${ }^{24}$ Yves Mény \& Yves Surel, Par le peuple, pour le peuple: le populisme et les démocraties (2000).

${ }^{25}$ Michael Longo \& Philomena Murray, Europe's Legitimacy Crisis: From Causes to Solutions (2015); INNERARITY, supra note 10, at 4; Michael Goodhart, Europe's Democratic Deficits Through the Looking Glass: The European Union as a Challenge for Democracy, 5 PERSP. ON POL. 567 (2007); Yves Mény \& Yves Surel, The Constitutive Ambiguity of Populism, in Democracies AND The POPUlist CHALlenge 1-21 (Yves Mény \& Yves Surel eds., 2002). Contra Giandomenico Majone, Europe's 'democratic deficit': The Question of Standards, 4 EUR. L.J. 5 (1998); Andrew Moravcsik, In Defence of the 'Democratic Deficit': Reassessing Legitimacy in the European Union, 40 JCMS: J. COMMON MKT. STUD. (2002); Thomas Jensen, The Democratic Deficit of the European Union, 1 LIVING REV. DEMOCRACY 1 (2009).

${ }^{26}$ Andrea LP Pirro, et al., The Populist Politics of Euroscepticism in Times of Crisis: Comparative Conclusions, 38 POLITICS 378-90 (2018).

${ }^{27}$ Liesbet Hooghe \& Gary Marks, Sources of Euroscepticism, 42 ACTA POlitica 119 (2007); LiUbOMIR K. TOPALOFF, Political PARTIES AND EUROSCEPTICISM (2012); VollaARD, supra note 19; John Fitzgibbon, Citizens Against Europe? Civil Society and Eurosceptic Protest in Ireland, the United Kingdom and Denmark, 51 JCMS: J. CoMmON MKT. STUD. 105-15 (2013); Simon Usherwood, et al., Defining Euroscepticism: From a Broad Concept to a Field of Study, in THE Routledge HaNDBooK of Euroscepticism 3-10 (Benjamin Leruth, et al. eds., 2017).

${ }^{28}$ Blokker, supra note 23 , at 116.
} 
an opposition to the policies of European institutions and the necessity to disrupt the pillars of the economic, legal, political, and social organization under the project of "an ever-closer Union."

Actually, the anti-European sentiments, and their consequences in terms of populism or Euroscepticism, suggest the necessity to foster the creation of a European public sphere ${ }^{29}$ that is both within and across national borders and through which it is possible to establish the right of "an organized opposition to appeal for votes against the government and in elections." ${ }^{30}$ In this vein EU integration must evolve, not only opening institutions to their citizens and making them more responsible, but also creating an arena for public debate and giving the right to organize opposition within the system. As Held has alleged "an equal right to liberty and self-development can only be achieved in a participatory society, a society which fosters a sense of political efficacy, nurtures a concern for collective problems and contributes to the formation of a knowledgeable citizenry capable of taking a sustained interest in the governing process." 31

The public dimension and the channels of opposition must fit together and for this to be possible, citizens' behavior and preferences should constitute a formal constraint for policy makers. Decisions at the EU level should be taken by political elites with the complementary help of citizens, and under the eyes of powerful oppositions. If it is impossible to create a public arena in which to hold European governance accountable, people will almost inevitably be thrust into orchestrated antagonism to Europe. Over the last few decades, we have seen that the absence of a European public sphere where people are able to organize opposition in the EU has forced them to organize opposition to the EU. ${ }^{32}$ This is not a subtle tactic to justify populism or Euroscepticism, but a way to say that we always need places where political conflict emerges and is channeled into institutional life; otherwise, the mobilization of an opposition against EU polity is inevitable, without relevance or distinction between European or national levels. To use the insight of Andrea Simoncini, European constitutionalism is today sustainable only through the existence of a dialogic interaction between a judicial, political, and civic dimension; the latter being the third pillar of a composite "constitutional space" where democracy at both European and state levels exists. ${ }^{33}$

The ECI - with its merits and flaws_- presents a highly intriguing test case regarding the connection between an institutionalized European civil society system and the creation of channels for criticizing or helping reform EU institutions.

\section{Finding a tool to meet populism on its terrain}

Insofar as the ECI offers a route for direct popular engagement in policy-making, it potentially responds to populist critique of the EU. As we shall see, however, the operation of the ECI has failed to completely fulfill this promise. After Maastricht and then during the work of the Convention on the future of Europe (2002-2003), European Institutions put great effort into increasing citizens' participation in supranational activities. ${ }^{34}$ Various mechanisms of direct citizens' participation, mostly designed to encourage the work of the Commission, were introduced to

\footnotetext{
${ }^{29}$ This aspiration is close to that expressed by Jürgen Habermas \& Jacques Derrida, February 15, or What Binds Europeans Together: A Plea for a Common Foreign Policy, Beginning in the Core of Europe, 10 Constellations 291-97 (2003), and then Jürgen Habermas, Europe: The Faltering Project 79 et seq. (2009); Jürgen Habermas, The Crisis of the European UNION: A RESPONSE (2012).

${ }^{30}$ Peter Mair, Political Opposition and the European Union, 42 Gov'T AND OPPOsITION 7 (2007).

${ }^{31}$ David Held, Models of DEMOCRACY 234 (2006).

${ }^{32}$ Mair, supra note 30 , at 7.

${ }^{33}$ Andrea Simoncini, The European Union as a "3- $d$ " Constitutional Space, 21 MAASTRICHT L.J. 247-48 (2014). The author speaks of a new deficit at the European level which affects participatory democracy and is then "civic."

${ }^{34} \mathrm{After}$ the adoption of Maastricht Treaty a few quasi-political rights were added to benefit the European citizens, including the right to petition before the EU institutions (Article 21 of TEC, now Article 24 TFEU), bodies and offices and the right to complain to the European Ombudsman (Articles 21 and 195 TEC, now Articles 24 and 228 TFEU).
} 
educate and inform the public about the most important political decisions in the process of European construction.

In order to create the forms of a more democratic Union, to recognize the pluralism in the EU "constitutional space," 35 and to encourage active cross-border public debates, the Convention introduced the ECI as a new right to enhance citizens' participation in democratic life (Article I-46(4)). ${ }^{36}$ This new instrument, the ECI, allowed people to submit proposals to change legal acts of the Union, provided they had the support of at least one million people.

After the failure of the Convention, the new instrument was left on the agenda at the Intergovernmental Conference which was charged with completing the "Reform Treaty." ${ }^{37}$ With little debate and slight modification, the ECI passed into both the revised Treaty on European Union (TEU) and the Treaty on the Functioning of the European Union (TFEU). The legal basis of the new mechanism for participatory democracy is now set forth in two legal dispositions: Article 11, paragraph 4, of the TEU, which states the substantive aspects of the citizens' initiative, as it provides for both its scope and its limits, ${ }^{38}$ and Article 24 of the TFEU, which determines the procedural aspects of the ECI by requiring its implementation by means of a Regulation. ${ }^{39}$ The application of TEU Article 11, paragraph 4, was quite rapid. Before the new Treaties came into force, the Commission published a Green Paper on a European Citizens' Initiative. ${ }^{40}$ The document went the same way as the introduction of the ECI into the institutional framework of the

\footnotetext{
${ }^{35}$ Andrea Simoncini, Beyond Representative Democracy: The Challenge of Participatory Democracy and the Boundless Galaxy of Civil Society, in Democracy and Subsidiarity in the EU. National Parliaments, Regions and Civil Society in the Decision-Making Process, 46 et seq. (Marta Cartabia, et al. eds., 2013).

${ }^{36}$ In the very last session of the Convention, German MP Jürgen Meyer promoted the introduction of a new mechanism of participatory democracy as part of a broader article on EU democracy (See Jürgen Meyer, Suggestion for Amendment to Article I-46 of the Treaty Establishing a Constitution for Europe, http://european-convention.eu.int/Docs/Treaty/pdf/34/ 34_Art\%20I\%2046\%20Meyer\%20EN.pdf. Similar proposals were presented by J. Borrell, C. Carnero, D. L. Garrido, Suggestion for Amendment to Article 34 of the Treaty Establishing a Constitution for Europe, http://european-convention. eu.int/Docs/Treaty/pdf/34/Art34bisBorrell.pdf; J. Voggenhuber, R. Wagener, N. MacCormick, E. Lichtenberger, M. Nagy, Suggestion for Amendment to Article 34 of the Treaty Establishing a Constitution for Europe, http://european-convention. eu.int/Docs/Treaty/pdf/34/Art34Voggenhuber.pdf.). Although the Presidium formally refused the introduction of this proposal, in one of the last meetings of the Convention, the President Giscard d'Estaing announced a series of last-minute amendments to the proposed Constitution. Consequently, the ECI was included within the Article I-46(4) (Principle of participatory democracy).

No less than one million citizens coming from a significant number of MS may invite the Commission to submit any appropriate proposal on matters where citizens consider that a legal act of the Union is required for the purpose of implementing the Constitution. A European law shall determine the provisions for the specific procedures and conditions required for such a citizens' initiative.

Andres Auer, European Citizens' Initiative: Article I-46.4 Draft Convention, 1 Eur. Const. L. Rev. 79 (2005).

${ }^{37}$ See Paul Craig, The Lisbon Treaty: law, politics, and treaty reform 20 (2010).

${ }^{38}$ Article 11(4) provides that: "Not less than one million citizens who are nationals of a significant number of Member States may take the initiative of inviting the European Commission, within the framework of its powers, to submit any appropriate proposal on matters where the citizens consider that a legal act of the Union is required for the purpose of implementing the Treaties." Regarding Article 11, see Filippo Donati, Art. 11 (commento a), in Trattati Dell'Unione EUROPEA, (Antonio Tizzano ed. 2014); Paola Piroddi, Art. 11 (commento a), in Commentario breve ai Trattati dell'Unione europea, (Fausto Pocar \& Maria Caterina Baruffi eds., 2014); Ricardo Garcia Macho, Article 11 [Participatory Democracy, in THE Treaty On European Union (Teu): A Commentary 449-65 (Hermann-Josef Blanke \& Stelio Mangiameli eds., 2013); Craig, supra note 16, at 20; Francesco Maiani, Citizen Participation and the Lisbon Treaty: A Legal Perspective 9-10 (2011); Michele Morelli, LA DEMOCRAZIA PARTECIPATIVA NELLA GOVERNANCE DELL'UNiONE EUROPEA (2011); Armin von Bogdandy, The European Lesson for International Democracy: The Significance of Articles 9-12 EU Treaty for International Organizations, 23 EUR. J. INT'L L. 315-34 (2012).

39“The European Parliament and the Council, acting by means of regulations in accordance with the ordinary legislative procedure, shall adopt the provisions for the procedures and conditions required for a citizens' initiative within the meaning of Article 11 of the Treaty on European Union, including the minimum number of Member States from which such citizens must come."

${ }^{40}$ Commission Green Paper on a European Citizens' Initiative, COM (2009) 622 final (Nov. 11, 2009).
} 
EU. ${ }^{41}$ A formal proposal for the first legislative regulation envisaged under Article 24 followed several months after the adoption of the Green Paper. ${ }^{42}$ On February 16, 2011, the European Parliament and the Council of the EU adopted Regulation No. 211/2011.43

The new regulation set forth the "threshold requirements" necessary to submit a proposal to the Commission. ${ }^{44}$ It allows promoters of ECIs (Committee) to freely choose the subject of an ECI. The initiative, however, cannot be designed to merely "criticize" policies or action undertaken by the Commission; ${ }^{45}$ it should maintain a "normative purpose" containing the promotion of new laws, the amendment of existing laws, or the repeal of previous legislation. ${ }^{46}$ Importantly, the Commission could either accept or refuse the registration of the proposal. ${ }^{47}$ In the case of rejection, the Commission must inform the representative of the Committee about "the reasons for such refusal and of all possible judicial and extrajudicial remedies available to them." ${ }^{48}$ If the Commission registers the initiative, a one year limit begins during which the Committee has to gather-either on paper or online-one million statements of support. ${ }^{49}$ Once the statements

\footnotetext{
${ }^{41}$ As expressed in the Green Paper: "Given the importance of the future proposal for citizens, organized civil society, stakeholders and public authorities in the Member States, citizens and all interested parties also need to give their views on how the citizens' initiative should work." Between November 2009 and January 2010, and after the issuing of the Green Paper, a period of consultation took place allowing for the involvement of a broad range of actors. Specifically, 329 replies were received from stakeholders, individual citizens, organizations and public authorities. See Commission, Outcome of the public consultation on the Green Paper on a European Citizens' Initiative, COM (2010) 119 final (Mar. 31, 2010). Dorota Szeligowska \& Elitsa Mincheva, The European Citizens' Initiative-Empowering European Citizens within the Institutional Triangle: A Political and Legal Analysis, 13 PERSP. ON EUR. POL. AND SOC'Y 56 (2012). As noted, "all the stakeholders shared the positive attitude towards both the introduction of the ECI and the establishment of a citizen-friendly, accessible and simple procedure which could contribute to make this first direct-democratic tool at the transnational level a success." See Susan Rose-Ackerman, Regulation and Public Law in Comparative Perspective, 60 U. TORONTO L.J. (2010). For more comments to the process of adoption of the regulation see Bruno Kaufmann, Transnational 'Babystep': The European Citizens' Initiative, in CITIZENS' initiatives in Europe. Procedures AND CONSEQuenCES of AgENDA-SETTING BY Citizens, 233-34 (Maija Setälä ed. 2012).

${ }^{42}$ The main actors in the process to establish a regulation for the ECI have been the Commission and the European Parliament. Even other European institutions played a specific role in the making of the draft regulation, such as the Committee of the Regions (CoR) and the European Economic and Social Committee (EESC). These actors proposed several amendments to the draft of the Regulation in order to made the ECI more "user friendly." See the Opinion of the EESC on "The implementation of the Lisbon Treaty: Participatory democracy and the citizens' initiative (Art. 11)," 2010 O.J. (C 354$) 59$.

${ }^{43} \mathrm{~A}$ detailed description of these steps is in Michael Dougan, What Are We to Make of the Citizens' Initiative?, 48 COMMON MKT. L. REV. 1807 (2011).

${ }^{44}$ In accordance with Article 3(1) of the Regulation, the organizers shall be citizens of the Union and of the age to be entitled to vote in elections to the European Parliament. Even if it is not specified into the Regulation, organizers must be natural persons. They need to set up a "Citizens' Committee" of at least seven persons who are residents of at least seven different Member States (hereinafter MS). Whereas the signatories need to be citizens of the Union and have the age to vote in elections to the European Parliament. See Art. 3(2) of the Regulation.

${ }^{45}$ Commission Regulation 211/2011, 2011 J.O. (L 650) Art. 4, para. 2: “(c) the proposed citizens' initiative is not manifestly abusive, frivolous or vexatious; and (d) the proposed citizens' initiative is not manifestly contrary to the values of the Union as set out in Article 2 TEU."

${ }^{46} I d$. Art. 4, para. 2 (“(b) the proposed citizens' initiative does not manifestly fall outside the framework of the Commission's powers to submit a proposal for a legal act of the Union for the purpose of implementing the Treaties.”).

${ }^{47}$ Committees must register their initiative with the Commission, which has two months to accept or refuse the registration in accordance with the conditions of Art. 4, para. 2.

${ }^{48}$ The potential review of the General Court can be invoked to complain about the Commission's failure to adequately justify the decision, which can be considered as an infringement of an essential procedural requirement. See Art. 4, para. 3. The Commission should avoid replying without reasons of rejection, such as "the proposal is beyond our competences" or "this is conflicting with the values stated in the Treaties". See Pawel Glogowski \& Andreas Maurer, The European Citizens 'Initiative-Chances, Constraints and Limits, IHS POLITICAL SCIENCE SERIES 1, 11 (2013)). The Committee also has the right to complain to the European Ombudsman, especially regarding procedural matters. Even the European Parliament could be involved in this process due the role of it as democratic institution. See Bruno De Witte et al., Legislating after Lisbon. New Opportunities for the European Parliament 1 (2010), https:/www.eui.eu/Projects/EUDO/Documents/EUDO1web.pdf.

${ }^{49}$ The online collection follows the rules set forth in Article 6. There is a threshold of statements for each Member State (the statements must be collected in at least 7 countries), which correspond to the number of the Members of the European Parliament elected in each MS, multiplied by 750 (Article 7, paragraph 2). Successful ECIs will be followed-up by an official
} 
have been collected, the organizers must submit them to the competent national authorities for verification and certification. ${ }^{50}$

The next step is the submission to the Commission, together with information regarding any support and funding received for that initiative. ${ }^{51}$ The Commission is then obliged to examine the initiative, but it is not forced to take any form of action. To support their initiative, the Committees only have the right to present the initiative at the European Parliament during a public hearing. In this phase the Commission retains more discretionary power than in the admissibility phase: It has absolute discretion on how to proceed with an ECI. Article 10, paragraph 1, of the Regulation formally requires that the Commission “(c) within three months, set out in a communication its legal and political conclusions on the citizens' initiative, the action it intends to take, if any, and its reasons for taking or not taking that action." 52 According to Regulation 211/2011, from April 1, 2012 and every three years afterwards, the EU Commission must present a report on the implementation of the Regulation. The first was released in March 2015 and since then many proposals to amend the ECI have been produced. ${ }^{53}$

Hence, the ECI represents an unprecedented means of transnational democracy, insofar as it seeks to establish the conditions for an additional direct connection between European citizens and EU institutions. The ECI started out with significant expectations from all sides, including policy-makers who saw it as a democratically legitimizing tool to move to a more "democratic Europe." 54 This innovation has been seen as being more of an informal rather than a formal tool of democratic participation, and "foreseen as complementary to the existing formal participatory mechanisms, pillars of the representative democracy." ${ }^{55}$ For many, it represented a change in the EU political environment because for the first time citizens arrived in Brussels, "creating a new political bottom-up 'actor' and having the power to influence the making of EU secondary legislation." 56

While at the beginning of this experience many scholars enthusiastically studied this new democratic tool, and had many expectations for it, now that the ECI has produced its first results, the comments have become increasingly lukewarm. Between April 1, 2012 and July 20, 2018, the Commission registered more than 70 initiatives and rejected 20 of them. Nevertheless, only a few initiatives reached one million signatures and only three have already received formal feedback from the European Commission. More importantly, however, the outcomes are a long way from the expectations, and very distant from creating a really bottom-up process of legislative initiative. ${ }^{57}$ During the first years of life, the ECI manifested problematic issues at every stage of the

hearing in the European Parliament (EP). The Commission (and further EU institutions as well as other governmental and non-governmental offices across Europe) will offer assistance and support during an initiative process. Differently from other instruments of direct democracy, such as the Italian "abrogative referendum" or the other forms of direct democracy, the Regulation use the word "statement" for the expression of support.

${ }^{50}$ Commission Regulation 211/2011, Art. 8, para. 1.

${ }^{51}$ Id. Art. 9.

${ }^{52}$ According to Art. 10, para. 2, "The communication referred to in paragraph 1(c) shall be notified to the organisers as well as to the European Parliament and the Council and shall be made public."

${ }^{53}$ Commission Report on the application of Regulation (EU) No. 211/2011 on the citizens' initiative, COM (2015) 145 final (Mar. 31, 2015).

${ }^{54} \mathrm{By}$ introducing this new civic engagement, the Treaty of Lisbon tries to reduce the problem of the "disconnection" between citizens and decision-maker in Brussels. See Graham Smith, The European Citizens' Initiative: A New Institution for Empowering Europe's Citizens?, in EMPOWERMENT AND DISEMPOWERMENT OF THE EUROPEAN CITIZEN, (Michael Dougan, et al. eds., 2012).

${ }^{55}$ See Szeligowska \& Mincheva, supra note 41, at 270.

${ }^{56}$ See Markus Thiel \& Oana Petrescu, Institutional Instruments for Citizen Involvement and Participation: Their Impact on the EU's Political Processes and Institutional Legitimacy, in Democratic Legitimacy in the European Union and Global Governance: Building a European Demos, 18-19 (Beatriz Pérez de las Heras ed. 2016).

${ }^{57}$ These initiatives are: "Right2Water" also known as "Water and Sanitation are a Human Right! Water is a Public Good, Not a Commodity!” (1,880,457 signatures), “One of us" (1,896,852 signatures) and “Stop Vivisection” (1,326,807 signatures); "Ban glyphosate and protect people and the environment from toxic pesticides" (1,320,517 signatures). 
procedure. ${ }^{58}$ As a consequence, after a formal EU Parliamentary Resolution, the Commission launched an online consultation with the aim of receiving feedback on possible amendments to the Regulation. ${ }^{59}$

\section{Harmonizing "electronic" with traditional forms of democracy}

The ECI represents a new generation of democracy instruments with a more direct and transnational value than any other participatory procedure before it and, possibly, a tool that meets the needs of e-participation and e-democracy in the $21^{\text {st }}$ century. ${ }^{60}$ More importantly than in other fields, the relationship between the Information Communication Technology (ICT) and democracy in the case of the ECI has been considered by EU institutions as a possible way, among others, of solving the many issues related to democratic governance and legitimacy deficits. ${ }^{61}$ It certainly represents a novel participatory instrument, granting citizens the opportunity to present legislative initiatives. In this process, the procedural benefits of electronic participation are undisputed. As the report of the European Commission states when evaluating the first three years of the ECI, almost $55 \%$ of the statements were collected online. If we compare these results with the expectations, however, this is a failure. ${ }^{62}$ Indeed, IT has been the most severe issue that organizers, mainly the unorganized civil society, have faced. ${ }^{63}$

While the ECI relies mostly on an e-participatory framework, and increases discussions on topics related to the EU, it also raises a problem of coordination between the role of civil society and the possibility of individuals and European institutions using the web as a way of inducing vast numbers of EU citizens to give their support to initiatives. As the results of the requested and admitted initiatives show, in the majority of cases, participation has been quantitatively a failure, since the proponents have not been able to usher the expected number of EU citizens. For organizations that do not already have a vast number of associates and a strong link with other associations based in other countries, mobilizing a wider public has been quite a fiasco. Several reasons could explain this result, including a lack of electronic preparation on the part of the organizers and the difficulty in using the Commission-run central online collection system for online campaigning. ${ }^{64}$

On balance, it must be concluded that the basic logic of representative democracy has not been altered, and participation currently accounts for only a few issues in the law and policy-making of

\footnotetext{
${ }^{58}$ See Commission Report supra note 53. For a comment of the Report see Thiel \& Petrescu, supra note 56, at 19.

${ }^{59} \mathrm{See}$ "Public Consultation on the European Citizens' Initiative", ec.europa.eu/info/consultations/public-consultationeuropean-citizens-initiative_en\#about-this-consultation.

${ }^{60}$ See Sandro Staiano, La rappresentanza, RIVISTA AIC (2017); Thorsten D. Barth \& Willi Schlegelmilch, The Quality of Democracy as a Key to Cyber Democracy, in Handbook of Cyber-Development, Cyber-Democracy, AND CyberDefEnse, 1-21, (Elias G. Carayannis, et al. eds., 2017); Lara Trucco, Il voto elettronico nel quadro della democrazia digitale, in Diritti e libertà in Internet, 427-39 (Tommaso Edoardo Frosini, et al. eds., 2017).

${ }^{61}$ The ECI belongs to what has been called the "participatory turn": I.e. increasing participation of citizens and civil society into European affairs. Sabine Saurugger, The Social Construction of the Participatory Turn: The Emergence of a Norm in the European Union, 49 EUR. J. OF POL. Res. 471 (2010). The European Commission in the famous White Paper on Governance proposed open policy-making routines for the involvement of citizens and organization. Communication from the Commission on the European Citizens' Initiative "Ban glyphosate and protect people and environment from toxic pesticides" COM (2017) 8414 final (Dec. 12, 2017).

${ }^{62}$ Through the use of the Internet the ECI aims at producing high degree of transparency, greater openness, and diversity of societal views represented at the EU level. See Beate Kohler-Koch, Civil Society and Democracy in the EU. High Expectations Under Empirical Scrutiny, in De-Mystification of Participatory Democracy: EU-Governance AND Civil SOCIETY 15 (Beate Kohler-Koch \& Christine Quittkat eds., 2013).

${ }^{63}$ Andrei Moraru, European Union Democratic Governance: A Case Study of the European Citizens' Initiative, 10 Europolity, 137 (2016).

${ }^{64}$ This issue has produced a lot of discussion among ECI scholars. See id. at 153; The ECI Campaign, 10 Reasons to Preserve ECI Organisers' Right and Freedom to Use Individual Online Collection Systems (Oct. 30, 2018), http://www.citizens-initiative. eu/10-reasons-to-preserve-eci-organisers-right-and-freedom-to-use-individual-online-collection-systems/.
} 
the EU, and only in an already institutionalized civil society environment. ${ }^{65}$ This means that the ECI does not achieve one of the main purposes the entire procedure aimed to fulfil: To create new networks across borders, strengthen the democratic system of the EU, and raise media awareness of European topics. ${ }^{66}$

\section{E. The difficult configuration of the ECl in the family of direct democracy mechanisms}

To understand whether the ECI can bring more democracy and participation into the EU polity, the first comments on the Convention's Draft Constitution of 2003 mentioned what it is not: It falls outside the category of "petitions," nor is it a "popular motion" or a "popular initiative." 67 As a matter of fact, the ECI appears as a particular agenda initiative with a popular motion addressed to the Commission, because it is the Commission and not the Parliament that holds the right of legislative initiative. ${ }^{68}$

Although the Commission used the so-called method of "reasoning by analogy," basing the regulation on similar procedures at state level, no existing national model could simply be used as a model for the implementation of the ECI. ${ }^{69}$ It remains a hybrid tool which combines features of direct democracy - as it is the citizens who set law-making procedures in motion and spark an EU-wide debate - and indirect democracy — as the Commission maintains the ultimate power of initiative. $^{70}$

To be sure, it is difficult and insufficient to compare the ECI to similar procedures at the national level, ${ }^{71}$ but an analysis that highlights the differences between the ECI and similar institutions from national constitutionalism could help. This would be useful in understanding the failure of the procedure and the disparities between this instrument of participation and the way similar issues are managed at the state level; this is clearly evidence of the above-mentioned inability of the Commission and the Union to develop structures and processes that would adequately replicate even the imperfect practices of state democracies at the EU level.

To understand this problem, it is helpful to explore four features of the ECI: (a) who is the promoter of the initiative; (b) what they promote, and how; (c) who reviews and controls the procedure; (d) who is the beneficiary of the ECI. The first feature concerns the nature of the promoters. As we know, the right to advance an ECI is bestowed only on individual EU citizens. This is different from the right to petition (Article 227 of the TFEU) as this is a right reserved also for legal personnel residing or having their registered office in the territory of a Member State. The one million signatories should be citizens of at least one quarter of all Member States. Proposers are required to collect supporters in other countries separated by language, ethnicity, religion, or

\footnotetext{
${ }^{65}$ Kohler-Koch, supra note 62, at 15.

${ }^{66}$ Sergiu Gherghina \& Adriana Groh, A Poor Sales Pitch? The European citizens' initiative and attitudes toward the EU in Germany and the UK, 17 EUROPEAN POL. AND SOC'y 373, 375 (2016).

${ }^{67}$ Consisting of a demand made, by a certain number of citizens, to Parliament asking it to enact some law or to take a decision within the range of its powers and competencies. See Auer, supra note 36, at 76.

${ }^{68}$ Víctor Cuesta-López, A Comparative Approach to the Regulation on the European Citizens' Initiative, 13 PERSP. ON EUR. POL. AND SoC'Y 257 (2012); Anastasia Karatzia, The European Citizens' Initiative in Practice: Legal Admissibility Concerns, 40 EUR. L. REV. 509 (2015).

${ }^{69}$ Glogowski \& Maurer, supra note 48 , at 29.

${ }^{70}$ Szeligowska \& Mincheva, supra note 41 , at 278.

${ }^{71}$ Bouza Garcia \& Del Río Villar, supra note 16, at 316; Miguel Sousa Ferro, Popular Legislative Initiative in the EU: Alea Iacta Est, 26 Y.B. OF EUR. L. 355 (2007); Fabio Ferraro, Il diritto di iniziativa dei cittadini europei: uno strumento efficace di democrazia partecipativa?, 21 RIV. IT. DIR. PUBBL. COMUNIT. 727-737 (2011).
} 
culture. For this reason, the threshold of one million signatures to be collected in not less than seven states is higher than any similar instrument of direct democracy. ${ }^{72}$

The second feature concerns the subject-matter of the initiative and its promotion. It has already been mentioned that the ECI is only a proposition to eventually have a legislative initiative launched by the Commission. In many of the countries with citizens' initiatives, the right to submit proposals permits the legislative draft to be put directly before the legislatures-i.e. national Parliaments. In the case of the European Union this is not possible, due to the institutional and legal structure on which it is based: As a general rule, initiatives for EU legislation originate from the European Commission (Article 17 TEU). Thus, the ECI gives citizens only the right to request the Commission to make use of its initiative power. ${ }^{73}$ Therefore, the subject-matter of an ECI is quite different from both referenda and any other popular legislative initiative. Here, citizens have basically only the right to propose the insertion of a topic in the agenda of the Commission and nothing more. ${ }^{74}$

The third aspect concerns the reviews and controls made during the procedure. The Regulation sets forth two distinct controls: The preliminary check at the moment of registration and the control after the verification of signatures (Article 10). Unlike other national institutions, in the case of the ECI the same body (the Commission) wears two different hats: First, it assesses the admissibility of the initiative and, second, it has the duty to carry it out; whereas, in many member states different actors play this role, such as Constitutional or Supreme Court Judges and Parliamentary Committees. ${ }^{75}$ The Commission's preliminary examination diverges from similar constitutional or legal checks of other popular initiatives. Even if the Commission controls admissibility on the basis of strict regulatory criteria, the way Article 4 is drafted gives considerable discretion to Brussels. Moreover, the Regulation does not present a list of matters excluded from the scope of the ECI or the so-called requisite of the single subject to be chosen, which is quite common in comparative law where it is designed to preserve the coherence and substantive unity of the initiatives. $^{76}$

The fourth feature concerns the beneficiaries of the initiative. As well as analogous instruments from national constitutionalism, such as the Italian People's Legislative Proposition or the equivalent Austrian and Spanish institutions, to start an ECI there is a requirement for a "Committee" to be formed whose main aim is to defend the cause. Indeed, by means of an ECI, EU citizens seek unity in the midst of rich diversity in furtherance of the collective interest. Both the goal of an initiative and the general scope of reaching closer participation on a problem should be sufficient to encourage petitioners to embrace the duty of launching a widespread collection of statements of interest among EU citizens. Considering the European context and the cost of starting an initiative without certainty of the result, one must wonder whether the ECI could be considered as a mere motion of citizens acting alone. The cumulative requirements of geography and numbers of signatories make the organization of initiatives by citizens alone very difficult-i.e. without the support of an influential organization. This suggests the idea that the real beneficiaries of the

\footnotetext{
${ }^{72}$ It is also relevant that some aspects of the procedure remain "decentralized." The certification of statement of support is up to every MS. The coordinators of any ECI have to submit the collected statements of support for verification in the MS where the signatories originate-either by virtue of citizenship or residence.

${ }^{73}$ This right is only of an indirect nature. The ECI does not appear among the citizens' rights enumerated in Title V of the Charter of Fundamental Rights (Articles II-39 to II-46).

${ }^{74}$ This is a major divergence with many of the expressions of agenda initiative that are commonly drafted in a popular bill. See Cuesta-López, supra note 68, at 257-60.

${ }^{75}$ Some scholars critically observed that this rule could disorientate the proposers, because there is the objective possibility that the Commission could consider the initiative in the first stage as admissible, but then find it non-admissible at the moment of the examination under the Article 10. See Paolo Ponzano, L'initiative citoyenne européenne: la démocratie participative à l'épreuve, Revue du Droit DE L'Union EuropéEnne, 622 (2012).

${ }^{76}$ Cuesta-López, supra note 68.
} 
ECIs could be large pressure groups already present at EU level. ${ }^{77}$ The experience of the ECI has confirmed this view, since only a small percentage of initiatives reached the minimum number of statements necessary to be submitted to the Commission and-more importantly-in every case the advocates of the initiative were either well recognized NGOs or civil society associations.

The focus on who gains any advantage from the ECI helps us to discover another important aspect of direct democracy mechanisms: The necessity for evaluators to cumulatively verify the strong commitment of advocates and the feasibility of initiatives. For this reason, the practical implementation of the ECI is expected to push sponsors to learn from the experience of popular initiatives. For example, the sponsors could reinforce their initiative while drafting a legislative proposal during the collection of statements of interest. This could be of great help in understanding not only whether and how the motion complies with EU primary law and is confined to its legislative competencies, but also the suitable legal act that could follow the initiative. ${ }^{78}$ Moreover, as happens in many national citizens' initiatives, the right to formulate legislative proposals has the advantage of being a robust source for future civic debates.

\section{F. The admissibility check: how to combine citizens' civic advocacy and the discretionary power of the commission}

The ECI has stimulated quite a long list of initiatives in five years. They range from very specialized issues of concern to public interest groups to wide-ranging populist or even anti-populism campaigns. ${ }^{79}$ A quite interesting distinction that echoes the differences made in this special issue by Zoran Oklopcic. ${ }^{80}$

An example of the first group are initiatives like "Minority SafePack - one million signatures for diversity in Europe" or "Stop TTIP" or "Stop Plastic in the Sea." On the contrary, in the second group there is those initiatives aimed at expressing what "the people want" or being "against the political elite," ${ }^{11}$ such as "Let us reduce the wage and economic differences that tear the EU apart!"; "Suspension of the EU Climate and Energy Package"; "Unconditional Basic Income"; "A new EU legal norm, self-abolition of the European Parliament and its structures, must be immediately adopted"; "Stop starvation for $8 \%$ of the European population"; and "Stop TTIP and CETA." 82 A good example of the third group is "Wake up Europe! Agir pour préserver le projet démocratique européen," which was launched in November 2015 in light of the increasingly authoritarian policies of some European governments to help civil society contrast "populist discourses and policies that shrink the democratic space." 83

The debate over the feasibility of ECIs has been focused on issues related to the initial check of the Commission regarding the admissibility of the proposal. ${ }^{84}$ The regulation spells out the limits to the material scope of an initiative, laying down which conditions are applicable for registration. First, it provides that the Commission can refuse to register an initiative that falls "manifestly

\footnotetext{
${ }^{77}$ First commentators stressed that the ECI was addressed to become a way through which organized civil society could make transnational alliances in order to contribute to the development of European polity. See Simoncini, supra note 35, at 52.

${ }^{78}$ Víctor Cuesta-López, The Lisbon Treaty's Provisions on Democratic Principles: A legal Framework for Participatory Democracy, 16 Eur. Pub. L. 123 (2010).

${ }^{79}$ See European Commission, http://ec.europa.eu/citizens-initiative/public/?lg=en (last accessed September 21, 2018).

${ }^{80}$ See Zoran Oklopcic, Imagined Ideologies: Populist Incarnations, Liberalist Projections, and the Horizon of Constitutionalism.

${ }^{81}$ For this consideration of "populism", see David Prendergast, The Judicial Role in Protecting Democracy from Populism; see also HELD, supra note 31 (discussing the definition).

${ }^{82}$ As the same website of the Campaign states, "Stop TTIP and CETA" aims at stopping these two trade and investment agreements "because they pose a threat to democracy, the rule of law, the environment, health, public services as well as consumer and labour rights."

${ }^{83}$ See act4democracy, (last visited Feb, 12 2019), http://www.act4democracy.eu.

${ }^{84}$ In the first phase of the procedure the Commission has to assess the feasibility of each ECI by using the abovementioned rules set up in Art. 4(2) of the Regulation.
} 
outside the framework of the Commission's powers to submit a proposal for a legal act of the European Union. ..." 85 Determining whether the subject of a campaign falls outside the Commission's powers could be very difficult for people without professional or specialized knowledge in European law. ${ }^{86}$ Second, the proposed initiative should not be "manifestly abusive, frivolous or vexatious." Evidently this requisite refers to a scenario where ECIs are launched either to achieve an aim that is different from the adoption of a legislative act or to merely raise visibility in order to mount opposition against some European policy. ${ }^{87}$ Third, the ECI should not be manifestly contrary to the values of the EU as set out in Article 2 TEU; for instance, a proposed initiative should not violate the Charter of Fundamental Rights.

So far, the Commission has accepted forty-eight initiatives. ${ }^{88}$ Another fifteen initiatives have been declared "obsolete" after being withdrawn by the organizers; at least 22 requests have had registration refused by the Commission. ${ }^{89}$ The power of the Commission to reject initiatives under overly strict legal admissibility criteria has been fiercely criticized. This broad and "elitist" power is considered to have limited the power of the ECI to promote participation through public debate and to directly influence the EU agenda.

By looking at the letters explaining rejections we can understand why this power is wrongly used, and how they frequently can lead to legal claims. The Commission, in fact, essentially follows the same rationale in every letter. ${ }^{90}$ First, it points out the absence of a proper legal basis and, second, the practical impossibility of conferring to itself the power to propose the legal act requested. ${ }^{91}$ The only dissimilarity lies in the gravity of the error made by the Committees at the moment of choosing the legal basis, which varies from the selection of the improper article of the treaty to its wrongful interpretation. In all these letters the Commission implies it lacks the power of initiative because of the "absence" of a valid legal basis in the proposal.

\footnotetext{
${ }^{85} \mathrm{By}$ virtue of the TEU, the Commission is the only body entitled to put forward new legislative proposal (Art. 17(2) TEU). There are two narrow exceptions to this rule: First, foreign and security policy, where the right of initiative belongs to the MS and the High Representative (Art. 30 TEU); second, justice and home affairs, for which the Commission shares the right of legislative initiative with one-quarter of MS (but not, in this case either, with the European legislative instances) (Art. 76 TEU).

${ }^{86}$ The term "manifestly" could suggest that the decision as to the existence of competence is not a final one-i.e. at the stage of registration there is an entire but not a full admissibility check; ultimately it is up to the Court of Justice of the EU to determine whether a proposal falls outside the initiative power of the Commission.

${ }^{87}$ See Nikos Vogiatzis, Is the European Citizen's Initiative a Serious Threat for the Community Method, 6 EUR. J. LEGAL STUD. 126-28 (2013).

${ }^{88}$ The subject of the initiatives varies considerably: From supporting educational programs such as Erasmus, to climate protection, to granting EU citizens residing in another Member State the right to vote in all political elections in their country of residence, on the same conditions as the nationals of that State, to affirming the right to water for everyone. The initiative "Water and sanitation are a human right! Water is a public good, not a commodity!" is the first ECI in European history to have succeeded in collecting the minimum number of signatures. On this ECI see Andreas Bieler, Fighting for Public Water: The First Successful European Citizens' Initiative, "Water and Sanitation are a Human Right", 9 INTERFACE (2017). For a complete list of the initiatives it is possible to consult the website of the Commission, see http://ec.europa.eu/citizens-initiative/public/ welcome (last visited Feb, 14 2019).

${ }^{89}$ Some of these refusals appeared immediately to be disputable. See Simoncini, supra note 35, at 64-65.

${ }^{90} \mathrm{My}$ vote against nuclear power was the first ECI to be rejected by the European Commission. In its letter to the Committee explaining the reasons for the refusal, the Commission alleged that an ECI cannot be based on the Euratom Treaty for the promotion of nuclear energy. The Commission affirmed "the Euratom Treaty does not include any provision on the citizens' initiative and Articles 11 of the TEU and 24 of the Treaty on the Functioning of the European Union (TFEU) are not among the provisions of the TEU and of the TFEU that are applicable in accordance with Article $106 a$ of the Euratom Treaty." The letter continues stating that "the legal bases of the TEU and TFEU cannot be interpreted as giving the Commission the possibility to propose a legal act that would have the effect of modifying/repealing provisions of primary law (namely the Euratom Treaty)". All the letters are available for download on the website of the Commission: http://ec.europa.eu/citizensinitiative/public/initiatives/non-registered.

${ }^{91}$ The Commission uses in every case the condition set out under the letter (b) of Art. 4(2) of the Regulation-i.e. the initiative "falls manifestly outside the framework of the Commission's powers to submit a proposal for a legal act of the Union for the purpose of implementing the Treaties."
} 
Changes in the usual procedure can be found in some letters, when the Commission illustrates why the registration has been refused, even though the Union institutions are bound in their acts to respect the values or the principles that an initiative aims to perform. One of most interesting examples of this phenomenon is the initiative for the abolition of Spanish Corridas (bullfighting). ${ }^{92}$ Here, the reasoning of the Commission is all but laconic. The Commission's letter explained why-even if the Commission had promoted the welfare of animals in many circumstances and another ECI in the area of animal welfare had already been accepted (concerning dairy cows) - the initiative about the abolition of Corridas fell short of a valid legal basis in the treaties. ${ }^{93}$ Interestingly, the Commission also mentioned the ruling of the ECJ in Jippes, in which the Court recognized that "ensuring the welfare of animals does not form part of the objectives of the Treaty, as defined in Article $2 \mathrm{EC}$, and that no such requirement is mentioned in Article $33 \mathrm{EC}$, which sets out the objectives of the common agricultural policy." 94

Even the rejection of the initiative Minority SafePack-one million signatures for diversity in Europe, an initiative for proposing laws that enable the promotion of minority rights, language rights, and the protection of their cultures, ${ }^{95}$ relies on different reasoning. In its letter, the Commission declared that some of the acts requested in the Annex of the initiative "might individually fall within the framework of the Commission's power to submit a proposal for a legal act of the Union for the purpose of implementing the Treaties." ${ }^{\prime 6}$ As will be explained later, in this case the Court has ruled on this specific issue and has imposed the admittance of the initiative on the Commission.

Indeed, the decision not to register an initiative is a matter subject to judicial review. There are two ways for the organizers to do this: First, they can start an action of annulment under Article 263 TFEU; second, they can file a complaint with the European Ombudsman under the conditions specified in Article 228 of the TFEU.

So far (February, 14 2019), the General Court has reviewed seven rejections. ${ }^{97}$ In two cases the Court annulled the Commission's decision; these cases have, therefore, now been registered on the Commission's website as open to signatories. ${ }^{98}$ In another case, after the judgment of the Court to dismiss the action, the applicant lodged an appeal before the Court of the European Union. The Court of the European Union delivered its decision on September 12, 2017, refusing to set aside the judgement of the General Court. ${ }^{99}$ The decisions of the European Courts cast light on the Commission's legal obligations during the registration stage, but perhaps also-as has been pointed out - on the perennial question of the division of competencies between the EU and Member States. ${ }^{100}$ In the two cases where it was decided to dismiss the action taken by the Committees, the General Court confirmed that the interpretation of Article 4, paragraph 2, (b) of the Regulation must be in accordance with the "principle of conferral" (Article 13, paragraph 2,

\footnotetext{
92“Abolición en Europa de la tauromaquia y la utilización de toros en fiestas de crueldad y tortura por diversion." The initiative was refused on July 19, 2012, C (2012) 5222 final.

${ }^{93}$ For more see Andrea Simoncini, The European Union as a "3-D" Constitutional Space, 21 MaASTRICHT L.J., 247-48 (2014). See Peters, supra note 14, at 64.

${ }^{94}$ See Case C-198/01 Consorzio Industrie Fiammiferi (CIF) v. Autorità Garante della Concorrenza e del Mercato (Sept. 9, 2003), http://curia.europa.eu/. In this sense, the abolition of 'corridas' represents an aim that falls outside the purpose of the Treaties and in particular of that situation in which the welfare of animals could be regulated at European level (e.g. Agriculture).

${ }^{95}$ For more, see http://www.minority-safepack.eu/ (last accessed November 2, 2018).

${ }^{96}$ Initiative refused on September 13, 2013, C(2013) 5969 final.

${ }^{97} \mathrm{~T}-754 / 14 ;$ T-361/14; T-44/14, T-646/13, T-529/13 e T-450/12.

${ }^{98}$ T-754/14 "Stop TTIP" and T-646/13 "Minority SafePack - one million signatures for diversity in Europe." The Commission adopted fresh decisions in order to comply with the judgments of the General Court; thus, these proposals were registered and reached more than one million of signatures.

${ }^{99} \mathrm{C}-589 / 15 \mathrm{P}$ "One million signatures for a Europe of solidarity."

${ }^{100}$ Nikos Vogiatzis, Between Discretion and Control: Reflections on the Institutional Position of the Commission Within the European Citizens' Initiative Process, 23 EUR. L.J. 258 (2017).
} 
of the TEU), ${ }^{101}$ and that Article 352 of the TFEU, which provides the so-called "flexibility-clause" of EU competences, can be used in the context of an ECI, insofar as it did not widen improperly the scope of EU powers or amend the Treaties. ${ }^{102}$ In the last two cases, which both annulled the Commission's decision, the General Court had the opportunity to provide guidance for understanding the ECI procedure. In one case, it struck down the decision to refuse the registration of the ECI on the grounds of "insufficient reasoning." 103 In the other, the General Court annulled the rejection of the Commission. ${ }^{104}$ In this decision the Court adopted a very interesting definition of a "legal act" of the European Union and linked it with the principle of democracy. ${ }^{105}$ By rejecting the Commission's argument that it is impossible to register an initiative that aims to disrupt the law-making process, the Court affirmed: "[T]here is nothing in Article 11(4) TEU or Article 2(1) ECI Regulation indicating that citizens cannot act through an ECI in order to prevent the adoption of a legal act."106

Although seen as the possibility to admit an ECI, these decisions do not seize the moment to give a clear definition of the Commission's discretion as a democratically accountable administrative power. ${ }^{107}$ In this sense, the General Court and the Court of Justice have lost the occasion to

\footnotetext{
${ }^{101} \mathrm{~T}-529 / 13$, para. 59.

${ }^{102} \mathrm{~T}-44 / 14$, para. 50-56.
}

${ }^{103}$ T-646/13 para. 29: “. . . the organisers were not, in any event, placed in a position to be able to identify those of the proposals set out in the annex to the proposed ECI which, according to that institution, fell outside the framework of its powers, within the meaning of Article 4(2)(b) of Regulation No 211/2011, or to know the reasons which led to that assessment and, therefore, were prevented from challenging the merits of that assessment, just as the Court is prevented from exercising its review of the legality of the Commission's assessment. Moreover, failing any complete statement of reasons, the possible introduction of a new proposed ECI, taking into account the Commission's objections on the admissibility of certain proposals, would be seriously compromised, as would also be the achievement of the objectives, referred to in recital 2 of Regulation No 211/2011, of encouraging participation by citizens in democratic life and of making the European Union more accessible." For a comment of this decision, see Andrea Simoncini, La prima sentenza che annulla il rifiuto da parte della Commissione di una proposta d'iniziativa popolare: una vera apertura alla democrazia partecipativa in Europa?, 37 QUADERNI COSTITUZIONALI 417 (2017); Nicole Lazzerini, Sulla possibilità di presentare un'iniziativa dei cittadini dell'Unione relativa a una "proposta complessa" e l'obbligo della Commissione europea di motivare in modo dettagliato il rifiuto di registrala: brevi considerazioni sulla sentenza Minority SafePack, 10 Osservatorio SULLE FONTI 1 (2017).

${ }^{104}$ The Commission has decided not to appeal the judgment http://europa.eu/rapid/press-release_IP-17-1872_en.htm.

${ }^{105} \mathrm{C}-754 / 14$ para. $37-38$ :

"[T]he principle of democracy, which, as it is stated in particular in the preamble to the EU Treaty, in Article 2 TEU and in the preamble to the Charter of Fundamental Rights of the European Union, is one of the fundamental values of the European Union, as is the objective specifically pursued by the ECI mechanism, which consists in improving the democratic functioning of the European Union by granting every citizen a general right to participate in democratic life ... requires an interpretation of the concept of legal act which covers legal acts such as a decision to open negotiations with a view to concluding an international agreement, which manifestly seeks to modify the legal order of the European Union.

The Commission's position, according to which it and the Council have sufficient indirect democratic legitimacy in order to adopt the other legal acts which do not produce legal effects vis-à-vis third parties, has the consequence of limiting considerably recourse to the ECI mechanism as an instrument of European Union citizen participation in the European Union's normative activity as carried out by means of the conclusion of international agreements. Insofar as the reasoning set out in the contested decision can therefore, where appropriate, be interpreted as definitively preventing European Union citizens from proposing any opening of negotiations relating to a new treaty to be negotiated by means of an ECI, that reasoning manifestly runs counter to the objectives pursued by the Treaties and by Regulation No 211/2011 and cannot, therefore, be admitted."

${ }^{106}$ For a comment see Anastasia Karatzia, New Developments in the Context of the European Citizens' Initiative: General Court Rules on "Stop TTIP", EU LAW ANALYsIs (May 18, 2017), http://eulawanalysis.blogspot.com/2017/05/newdevelopments-in-context-of-european.html.

${ }^{107}$ See Simoncini, supra note 35; Maximilian Conrad, The ECI's Contribution to the Emergence of a European Public Sphere, in Bridging the Gap? Opportunities and Constraints of the European Citizens' Initiative, 71-74 (Maximilian Conrad, et al. eds., 2016); Vogiatzis, supra note 86. On the principle of discretion, see Roberto Caranta, On Discretion, in The Coherence of EU Law: The Search for Unity in Divergent Concepts, 186 (Sacha Prechal \& Bert van Roermund eds., 2008). 
"push the integration further"108 and to provide reasoning that could be used in reforming participatory democracy in the EU.

\section{G. A weak and unconvincing procedure}

The follow-up phase is the stage that succeeds the twelve-month signature collection phase; it includes the Commission's decision on how to manage the requests made by the one million signatories. In this phase the Commission holds a broader discretionary power and the possibility of either hearing or not hearing the voice of the European people. ${ }^{109}$ Indeed, according to Article 10, paragraph 1 (c), of the Regulation, the only duty of the Commission is to inform the public about "the action it intends to take, if any, and its reasons for taking or not taking that action."

The six years were a source of frustration both among commentators and civil society actors. Only four initiatives reached the one million signature threshold. The decisions of the Commission on these initiatives have been very vague and have not produced clear-cut decisions. ${ }^{110}$ The legislative follow-up to the ECIs has been non-existent, so much so that some have argued that the ECI has the nature of an illusory initiative. ${ }^{111}$

The ECI Right 2 Water $^{112}$ is the first ECI to have produced some political-but not legalconsequences. Indeed, despite the great support for this initiative-more than 1.5 million signatures - the Commission decided not to take any legislative action following the campaign. In the same communication used to illustrate the reason for not taking any action after the initiative met the requirements, however, the Commission stated that it would "prepare a review of the Water Framework Directive and propose any necessary amendments to it" and would "launch an EU-wide public consultation on the Drinking Water Directive, notably in view of improving access to quality water in the EU." 113 As we understand it, the initiative has not produced any legal results, yet the people's contribution, which has been more on the public-discursive side of Union debates on water, is becoming a "policy-creating instrument that will improve citizens' influence in the EU political context." 114

In the other two cases in which the Commission had to decide which action to take, the declaration explaining why no legislative initiative would follow the ECI was greatly criticized. Hence, the organizers of the ECI One of Us decided to bring a formal action against the

\footnotetext{
${ }^{108}$ The European Court of Justice has played historically a big role in the process of integration, as Andrea Pin notes in his contribution to this special issue.

${ }^{109}$ Some authors stress the "non-binding" nature of ECI as the end of the story when it comes to the effect of this instrument into the EU institutional mechanism. See for example: Anastasia Karatzia, The European Citizens' Initiative and the EU institutional balance: On realism and the possibilities of affecting EU lawmaking, 54 COMMON MKT. L. REV. 177 (2017); Luis Bouza Garcia \& Justin Greenwood, What is a Successful ECI?, in BRIDGING THE GAP? Opportunities AND CONSTRAINTS OF THE European Citizens' Initiative (Maximilian Conrad, et al. eds., 2016); Maximilian Conrad \& Annette Knaut, Introduction: The ECI at Three - More Constraints than Opportunities?, in BRIDGING THE GAP? OpPORTUNITIES AND CONSTRAINTS OF THE European Citizens' Initiative, 10-15 (Maximilian Conrad, et al. eds., 2016); Christian Marxsen, Participatory Democracy in Europe: Article 11 TEU and the Legitimacy of the European Union, in WHAT FORM OF GOVERNMENT FOR THE EUROPEAN Union AND THE EuROzOnE? (Federico Fabbrini, et al. eds., 2015); Laurie Boussaguet, Participatory Mechanisms as Symbolic Policy Instruments?, 14 COMP. EuR. POL. 107 (2016).

${ }^{110} \mathrm{~A}$ summary of the decisions can be found in Karolina Borońska-Hryniewiecka \& Elizabeth Monaghan, The European Citizens' Initiative as Democratic Legitimacy-Enhancing Tool: Toward a Broader Conceptualization, in DemocRATIC Legitimacy in the European Union and Global Governance (Beatriz Pérez de las Heras ed. 2017).

${ }^{111}$ Karatzia, supra note 105 , at 180 .

${ }^{112}$ Launched on 10 May 2012 and submitted to the Commission on 20 December 2013.

${ }^{113}$ See Communication on the European Citizens' Initiative "Water and sanitation are a human right! Water is a public good, not a commodity!" (European Commission 2014).

${ }^{114}$ See Thiel \& Petrescu, supra note 56. The Communication expresses the idea that the Commission did commit itself to several actions to address the issue raised in the ECI in a non-legislative manner, as expressed by Borońska-Hryniewiecka \& Monaghan, supra note 109.
} 
European Commission before the Court of Justice, ${ }^{115}$ while the organizers of Stop Vivisection lodged a complaint with the European Ombudsman, which concluded on April 18, 2017 that the European Commission had "complied with its duty to explain, in a clear, comprehensible and detailed manner, its position and political choices regarding the objectives of the ECI" proposed. ${ }^{116}$ The last ECI to reach one million signatures is Ban glyphosate, which was submitted to the Commission on October 6, 2017. ${ }^{117}$ This case shares some of the characteristics of the ECI Right2Water, since the Commission has reviewed its decisions after an EU Parliamentary resolution, which had been urged following a "farmers' rebellion" and some other initiatives taken to revise the legislation. ${ }^{118}$ The Commission, indeed, has adopted a Communication on December 12, 2017 setting out a mix of actions mainly intended to enhance transparency and sustainability in the use of pesticides. ${ }^{119}$

Although the non-binding character of the ECI is in line with the construction of this instrument, and recalls a basic principle of the EU institutional and constitutional (incomplete) system-particularly the idea that the Commission cannot take instruction from other entitiesthe experience of these five years tells the story of a very weak and unconvincing participatory instrument. ${ }^{120}$ The ECI was supposed to become "a powerful agenda-setting tool in the hands of citizens," but the reality is very different from that aspiration. ${ }^{121}$

Part of the literature tries to explain this failure, stressing the multi-polar nature of the ECI. By using this narrative, these authors seek to soften the issues stating that "like other democratic innovations, the ECI should not be considered a unitary tool aimed at achieving a single end." 22 Even the European Ombudsman stressed that "the Commission coming forward with a legislative proposal should not be the only measure of success." 123 Although this justification is gaining a lot of followers, it is based on a poor argument, since the ECI "promises" European citizens not the mere possibility of rebelling, but the right to participate in the legislative process and prevent outrage. ${ }^{124}$ As the General Court affirms in Costantini: "[T]he ECI mechanism has as its subject matter or objective not initiating a mere dialogue between the citizens and the institutions but requesting the Commission, within the framework of its powers, to submit a proposal for an act." 125 Therefore, even if the Commission is the "playmaker" of legislative initiative, the importance of the ECI cannot be undermined by treating supporters

${ }^{115}$ On April 23, 2018 the General Court dismissed the action (Case T-561/14, ECLI:EU:T:2018:210) brought by the organizers of One-of-Us, who have appealed before the Court of Justice (case C-418/18 P). So far, the ECJ has not decided the case.

${ }^{116}$ Decision in case 1609/2016/JAS on the European Commission's response and follow-up to the European Citizens' Initiative "Stop Vivisection."

${ }^{117}$ See Communication from the Commission on the European Citizens' Initiative "Ban glyphosate and protect people and environment from toxic pesticides" supra note 61.

${ }^{118}$ See Britt E. Erickson, No consensus on glyphosate in the EU. Member states fail to agree on length of renewal, CHEMICAL AND ENGINEERING News (October 25, 2017), https:/cen.acs.org/content/cen/articles/95/i43/consensus-glyphosate-EU.html.

${ }^{119} \mathrm{See}$ Communication of the European Commission on European Citizens' Initiative "Ban glyphosate and protect people and the environment from toxic pesticides", December 12, 2017, C(2017) 8414 final. The Commission has also launched a REFIT of the General Food Law in order to address citizens' concerns. See Commission Staff Working Document of the REFIT evaluation of the General Food Law (Regulation (EC) No 178/2002), SWD (2018) 38 final.

${ }^{120}$ See Dougan, supra note 43, at 1842; Karatzia, supra note 68, at 180.

${ }^{121}$ A crystalline explanation of this "aspiration" can be found in Simoncini, supra note 35, at 49.

${ }^{122}$ Boronńska-Hryniewiecka \& Monaghan, supra note 109, at 41. The authors refer to the idea of GRAHAM SMITH, DEMOCRATIC INNOVATIONS: DESIGNING INSTITUTIONS FOR CITIZEN PARTICIPATION (2009).

${ }^{123}$ Decision of the European Ombudsman closing her own-initiative inquiry OI/9/2013/TN concerning the European Commission, European Ombudsman (Dec. 18, 2013) https://www.ombudsman.europa.eu/it/decision/en/59205.

${ }^{124}$ As the same document of the Ombudsman says in the same text: "While this is what the organisers of an ECI, on the face of it, seek to achieve, the Ombudsman's view is that the process itself is of major significance." Id. at para. 20. For more see Karatzia, supra note 68 , at 182.

${ }^{125}$ Case T-44/14 (para. 31). 
of the first trans-European form of democratic participation at the same level as mere interest groups whose aim is to lobby. The scope of the ECI should be to overcome this stage and become something more solid than a mere proposal to improve the policy design or the mere agenda of the Commission. ${ }^{126}$

\section{H. Concluding remarks}

This Article has attempted to look at the health of European democracy by examining the development of the European Citizens' Initiative. The ECI was introduced in Lisbon as an instrument to tackle both the disenchantment towards EU institutions and the feeling of disengagement from the political processes. The story of ECI shows two things: On one side, it sketches all the difficulties to correct EU integration in a way that is more open to welcoming the actual will of people; on the other side, it reveals the stringent necessity of creating a European public sphere before, and over, an economic union.

The analysis of the ECI has raised two important points. First, it has emerged that e-participation has too much of a lateral role in the overall framework of deliberative procedures, which is still dominated by the technocratic power of the Commission. This is not only a technical-i.e. informatics-problem, as the EU Commission assessed in 2015, but one of the most problematic issues harming the entire ECI procedure. ${ }^{127}$ Moreover, the emergence of a "cyber-public" sphere as an important part of European e-participation is called into question when it influences the way citizens and civil society organizations can participate in the EU decision-making process by using online tools. ${ }^{128}$ This is particularly true in the case of the ECI since citizens and civil society are seen as subjects that tend to conquer "arenas," where jealous political parties and institutions remain dominant. ${ }^{129}$ Second, although several initiatives obtained one million signatures, the EU Commission took further explicit informal steps with regard to two of these initiatives, namely the Right2Water and Ban Glyphosate. Even if this is evidence of the possibility of using an ECI as a "dialogue-enhancing tool," the opportunity of creating a secondbest solution must be put into specific and individual practices. The ECI could be used as a demonstration of EU institutions' intention to implement more open channels for public debate or even resentment. ${ }^{130}$

Therefore, insofar as the ECI competes with the Commission's right of legislative initiative, the possibility for people to propose new legislation might be considered as a way of limiting the Commission's prerogatives. ${ }^{131}$ As one would expect the Commission's approach has clearly blocked the amount and variety of democratic deliberation that the ECI can generate. This is particularly dangerous at a time when, after the results of the referendum in the UK on Brexit and the upcoming general election of the European Parliament, the need to reactivate the connection

\footnotetext{
${ }^{126}$ See Markus Thiel, European Civil Society and Human Rights Advocacy (2017); Christine Quittkat \& Peter Kotzian, Lobbying Via Consultation-Territorial and Functional Interests in the Commission's Consultation Regime, 33 J. EUR. INTEGRATION 401-18 (2011); Sabine Saurugger, Interest Groups and Democracy in the European Union, 31 WEST Eur. Pol. 1274-91 (2008); Luis BouZa Garcia, Participatory DEMOCracy and Civil SOCIETy IN THE EU: AgENDASETTING AND INSTITUTIONALISATION 19-40 (2015).

${ }^{127}$ Katrin Bottger \& Julian Plottka, The ECI - An Overview of Opportunities and Constraints, in BRIDGING THE Gap? Opportunities and Constraints of the European Citizens' Initiative, 21 (Maximilian Conrad, et al. eds., 2016).

${ }^{128}$ EU Parliament, Prospects for e-democracy in Europe, European Parliamentary Research Service EPRS, SCIENTIFIC FORESIGHT UNIT (STOA), February 2018 (PE603.213). www.europarl.europa.eu/RegData/etudes/STUD/2018/603213/ EPRS_STU(2018)603213_EN.pdf.

${ }^{129}$ Simoncini, supra note 35 at $45-73$.

${ }^{130}$ Thiel \& Petrescu, supra note 56.

${ }^{131}$ This is seen as an expression of the relevance of the "intergovernmentalist principle of the EU system." See Conrad, supra note 106 at $74-76$.
} 
between the EU and citizens is more urgent than in the past and new forms of people participation should go along with old forms of representative democracy. ${ }^{132}$

Based on this assumption, it is possible to draw two suggestions. The first regards the revision of the Regulation on the ECI-starting from the idea of distancing the ECI from the Commission and giving more powers both to the Parliament ${ }^{133}$-in the political phase that succeeds the 12 months after the signature, and to the European Court of Justice during the registration of initiatives. ${ }^{134}$ This is not only necessary to move the ECI closer to the family of "popular initiatives," but also for enhancing the democracy of the entire procedure and letting it evolve in the direction that the proposers of this mechanism foresaw at the very beginning during work on the "European Constitution." 135 Obviously, this should be coupled with a comprehensive simplification and reform of the ECI procedure, ${ }^{136}$ which might require not only legislative amendments, but also informatics improvements. ${ }^{137}$ It is a difficult task to undertake, but there is democratic participation at stake, and we do not have time to lag behind. ${ }^{138}$

Naturally, this cuts across the second conclusion, namely the problem of the idea of democracy underlying European integration. The troublesome introduction of the ECI offers some insights about how to manage the new reality of the European Union after the crisis of the Eurozone and the growth of populist parties and movements. Namely, it helps us to understand that the early vision of the Union as one of the main poles of a multipolar system has changed, yet has not been completely lost, ${ }^{139}$ just as the process of "democratization/constitutionalization" that Maastricht set in motion has not come to fruition, at least in the manner originally foreseen. $^{140}$

Therefore, if the EU is to get its house in order, politicians and bureaucrats need to accept the beginning of a new phase in the democratization/constitutionalization of Europe. This must be marked not by the ambitions of Maastricht, but a more reasonable idea of the work necessary to secure popular support for the European project, with the specific task of creating a pluralistic, civic space of dialogue among people and representatives, ${ }^{141}$ as well as new instruments for channeling the anger towards Europe into democratic forms of civic dialogue within European institutions. Without a common public sphere and a new foedus-namely a renovated alliance among Europeans and a valuable road for a new unitary sovereign power-the EU will always lack legitimacy in the eyes of people. But trust in the EU's values does not simply

\footnotetext{
${ }^{132}$ Anthony Arnull, Broken Bats, 41 Eur. L. REv. 474 (2016).

${ }^{133}$ The European Parliament has been a strong supporter of ECI since the origins. See Implementation of the European Citizens' Initiative: The Experience of the First Three Years (European Parliamentary Research Service 2015). A more active and pivotal role of the Parliament even in the ECI procedure has been yet remarked by some authors. See for example Michael Shackleton, Transforming Representative Democracy in the EU? The Role of the European Parliament, 39 J. EUR. INTEGRATION 191-205 (2017).

${ }^{134}$ As the European Parliament already has highlighted in its Report, see Towards a Revision of the European Citizen's Initiative? (European Parliament, Petitions Committee 2015).

${ }^{135}$ See Joana Mendes, Participation and the Role of the Law after Lisbon: A Legal View on Article 11 TEU, 48 COMMON MKT. L. REv. 1854 (2011). An interesting discussion on the democratic reform necessary at the EU level can be found in Mark Bevir \& Ryan Phillips, EU Democracy and the Treaty of Lisbon, 15 COMP. EUR. POL. 705-28 (2017).

136“An ECI both procedurally complex and simultaneously non-binding to the Commission cannot increase the EU's democratic credentials." See Vogiatzis, supra note 100.

${ }^{137}$ On this topic see also the proposals discussed during the annual ECI Days in April, 2017, hosted by the European Economic and Social Committee, http://www.eesc.europa.eu/agenda/our-events/events/eci-day-2017-i-participate. For more insights on the reform of the ECI, see http://www.citizens-initiative.eu/eci-reform-issues/.

${ }^{138}$ Enzo Cheli, Afterword, in A New Right for Democracy and Development in Europe: The European Citizens' INITIATIVE (ECI), 101-03 (Gianpiero Bordino ed. 2015).

${ }^{139}$ Karen E. Smith, Can the European Union be a Pole in a Multipolar World?, 48 THE InT'L SPECTATOR 114 et seq. (2013).

${ }^{140}$ Usherwood, supra note 3 , at 11 .

${ }^{141}$ One that overcomes the unfortunately incomplete theories of pluralism so far presented by European scholars. See Cuesta-López, supra note 68 at 21.
} 
materialize on demand. A new idea of Europe needs an effort of leadership and vision as well as "the enhancement of democratic processes of governance at the European not less than at the national scale." ${ }^{42}$ It is within this public and political space that the populist backlash and Euroscepticism could be flushed out and Monnet's ambition to create Europeans and European-ness could find full expression eventually.

\footnotetext{
${ }^{142}$ Pinelli, supra note 20 at 16.
}

Cite this article: Longo E (2019). The European Citizens' initiative: too much democracy for EU polity?. German Law Journal 20, 181-200. https://doi.org/10.1017/glj.2019.12 